\title{
Associations among the communities of soil-borne pathogens, soil edaphic properties and disease incidence in the field pea root rot complex
}

\author{
Kimberly Zitnick-Anderson • Luis E. del Río \\ Mendoza • Shana Forster • \\ Julie S. Pasche \\ Received: 13 April 2020 / Accepted: 15 October 2020 / Published online: 22 October 2020 \\ (C) The Author(s) 2020
}

\begin{abstract}
Background and aims Field pea production is greatly impacted by multiple soil-borne fungal and oomycete pathogens in a complex. The objectives of this research were to 1) identify the soil-borne pathogens associated with field pea in North Dakota and; 2) develop prediction models incorporating the occurrence of the soilborne pathogen communities, soil edaphic properties and disease incidence.

Methods Soil and plants were sampled from 60 field pea fields in North Dakota during 2014 and 2015. Plants (1500 across two years) were rated for both root rot and soil-borne pathogens isolated from roots. Soils were analyzed for edaphic properties. Indicator species analysis was used to identify soil-borne pathogen
\end{abstract}

Responsible Editor: Didier Lesueur

Electronic supplementary material The online version of this article (https://doi.org/10.1007/s11104-020-04745-4) contains supplementary material, which is available to authorized users.

K. Zitnick-Anderson

Department of Microbiology, North Dakota State University, Fargo, ND 58108-6050, USA

L. E. del Río Mendoza · J. S. Pasche $(\bowtie)$

Department of Plant Pathology, North Dakota State University, Fargo, ND 58108-6050, USA

e-mail: Julie.Pasche@NDSU.edu

S. Forster

North Central Research Extension Center, North Dakota State University, Minot, ND 58701, USA communities. Logistic regression was used to determine associations and develop prediction models.

Results Survey results from 2014 and 2015 indicated that the most prevalent soil-borne pathogens identified in field pea fields were Fusarium spp. and Aphanomyces euteiches. Five soil-borne pathogen communities were identified; three of which had statistically significant associations characterized by (1) Fusarium acuminatum, (3) A. euteiches, and (4) Fusarium sporotrichioides. The occurrence of the three communities were associated with clay content, soil $\mathrm{pH}, \mathrm{Fe}^{2+}$, and $\mathrm{K}^{+}$. Disease incidence was associated with the presence of either community 1 or 3 and $\mathrm{K}^{+}$.

Conclusions The results generated from this research will contribute to the development of management strategies by providing a soil-borne pathogen community prediction tool.

Keywords Soil-borne pathogens . Field pea root rot complex $\cdot$ Indicator species $\cdot$ Soil edaphic properties . Probability models

\section{Introduction}

US field pea (Pisum sativum L.) production occurs mainly in the Northern Great Plains, concentrated in Montana and North Dakota (www.nass.usda.gov). Aphanomyces root rot, caused by Aphanomyces euteiches Drechs, is responsible for shifting much of the pea production to drier environments with the intent of reducing favorable disease conditions 
(Papavizas and Ayers 1974). In North Dakota, field pea production reached a national high of 240,000 ha planted in 2006 (www.nass.usda.gov). Although production area rebounded to approximately 172,000 ha in 2019 after a low of less than 36,000 ha in 2011, production has not reached that previous high (www. nass.usda.gov). The occurrence of soil-borne pathogens has been theorized as one reason for the decline in production area. Similar to other broad leaf crops, field pea is susceptible to several soil-borne pathogens including Fusarium spp., Rhizoctonia solani Kühn, teleomorph Thanatephorus cucumeris (A.B. Frank) Donk, A. euteiches and Pythium spp. (Tu 1986, 1991).

The soil-borne fungal/oomycete pathogens associated with field pea have distinct life cycles. The oomycetes A. euteiches and Pythium spp. require free water to disseminate flagellated zoospores that "swim" toward plant roots guided by chemotaxis to serve as the primary source of inoculum (Agrios 1997; Dick 1990). As zoospores reach the roots, they encyst and begin to colonize the root system. The entire life cycle occurs within the soil environment. Although Fusarium spp. can vary in life cycle, in general, macroconidia form from perithecia to infect nearby plants. Some Fusarium spp. produce microconidia on conidiophores, which also can infect nearby plants. Some species form chlamydospores for long-term survival in the soil and others rely on colonizing plant debris for survival. Rhizoctonia solani is more commonly found in the soil environment in the asexual stage as vegetative mycelia and sclerotia which serve as survival structures (Agrios 1997). When weather and soil edaphic properties are optimal, soilborne pathogens reproduce, spread, and infect plant roots. This makes soil edaphic properties a critical aspect when considering the probability or likelihood of the presence of soil-borne pathogens in a field.

Research evaluating interactions between soil-borne pathogens associated with field peas and soil edaphic factors is limited. Texture, organic matter, and nutrient levels have been reported to have both positive and adverse effects on disease incidence caused by soilborne pathogens (Coyne 1999; Geense et al. 2015; Gregorich et al. 2006; Gu et al. 2020; Hillel 1998; Huber and Watson 1974; Lehmann et al. 2011; Rogovska et al. 2017; Stone et al. 2001). Soil texture is important in the dissemination and success of oomycete pathogens. Swimming zoospores of A. euteiches and Pythium spp. travel only as far as water capillaries and soil pores allow (Coyne 1999). These oomycetes are often more successful pathogens in clay soils, where moisture is greater due to lower porosity, than in sandy soils (Hillel 1998). In addition, clay soils retain highly decomposed organic matter, such as humus, which have been demonstrated to provide readily available nutrients for Pythium spp. and Aphanomyces spp. (Gregorich et al. 2006; Stone et al. 2001). The combination of greater soil moisture and humic organic matter, provides a favorable environment for zoospores to disseminate and infect.

Dissolved and particulate organic matter have demonstrated disease suppressive qualities in Fusarium wilt on banana, sudden death syndrome and common root rot on small grains, all caused by Fusarium spp. (Bailey and Lazarovits 2003; Geense et al. 2015; Lehmann et al. 2011; Peng et al. 1999). Dissolved and particulate organic matter reduced disease incidence by promoting greater microbial diversity and competition between pathogenic and nonpathogenic organisms over soil nutrients such as carbon and nitrogen (Franzluebbers et al. 1996; Mazzola et al. 2015; Raaijmakers and Mazzola 2016; Rogovska et al. 2017; Trivedi et al. 2015). The use of nitrogen fertilizers also has been observed to have deleterious effects on several soil-borne pathogens in labs and under field conditions (Datnoff et al. 2007). Previous research has indicated that the addition of nitrate containing fertilizers lowered disease severity caused by many root rot pathogens including Fusarium, Rhizoctonia, Aphanomyces, Cercosporella, Poria, and Armillaria (Gu et al. 2020; Huber and Watson 1974;). Although the addition of soil amendments such as particulate organic matter and nitrogen fertilizers has shown promising results, much of the previous research has been conducted only in controlled experiments and has not been evaluated in commercial crop production (Franzluebbers et al. 1996; Gu et al. 2020; Huber and Watson 1974; Mazzola et al. 2015; Raaijmakers and Mazzola 2016; Rogovska et al. 2017; Trivedi et al. 2015; Weller et al. 2002).

Soil edaphic factors might also influence the occurrence and structure of pathogen communities and disease incidence (Broders et al. 2009; Rojas et al. 2016; Zitnick-Anderson et al. 2017). Pythium community structure found in the Ohio Valley, Michigan, and Eastern North Dakota was correlated to soil factors such as: $\mathrm{pH}$, calcium, clay content, and cation exchange capacity (Broders et al. 2009; Rojas et al. 2016; ZitnickAnderson and Nelson 2015). Additionally, disease incidence was negatively correlated with cation exchange 
capacity, organic matter and calcium in the Ohio Valley (Broders et al. 2009). While research has begun to elucidate the associations between soil chemical/ physical properties and Pythium communities, little to no research has been conducted on the associations between the soil edaphic properties and soil-borne pathogens of field pea. The objectives of this research were to 1) identify the soil-borne pathogens associated with field pea in North Dakota and; 2) develop prediction models incorporating the occurrence of the soil-borne pathogen communities, soil edaphic properties and disease incidence. Understanding how the soil environment influences the presence of soil-borne pathogens is critical when structuring effective integrated pest management strategies (IPM) and developing disease prediction models. The development of such models could be used to improve the understanding of how the soil chemical and physical properties influence the occurrence of soil-borne pathogens and root rot severity in the field pea system.

\section{Materials and methods}

\section{Plant collection}

To identify soil-borne pathogens and characterize soilborne pathogen communities, field pea plants were collected at the v4 to 55 growth stage from 20 and 40 fields in June of 2014 and 2015, respectively (Supplementary Fig. S1). A total of 60 unique fields were sampled in 11 counties in the primary production region in northwestern North Dakota across the two years. Fields were chosen at a minimum of six km intervals. Five plants were collected in a ' $\mathrm{W}$ ' pattern at five sampling sites within each field ( 25 total plants per field), with at least $100 \mathrm{~m}$ between sampling sites. The plants were collected arbitrarily at each sampling site, regardless of the presence of disease symptoms. GPS coordinates were recorded for each sampling site in all fields. Plants were collected from a total of 100 and 200 sampling sites in 2014 and 2015, respectively. Across both years of the survey, 1500 total plants were evaluated. Plants were transported to the laboratory on ice and gently rinsed with luke-warm tap water to remove soil. Root tissue was surface sterilized for $30 \mathrm{~s}$ with a $0.8 \% \mathrm{NaOCl}$ solution. Plants were stored at $4{ }^{\circ} \mathrm{C}$ and processed within $48 \mathrm{~h}$.
Soil collection

Soil was collected from the same 60 fields as plants were sampled to develop prediction models incorporating soil-borne pathogen communities, soil properties and root rot incidence. Approximately $500 \mathrm{~g}$ of soil were collected using a garden spade to a depth of $25 \mathrm{~cm}$ from one or two plant sampling sites in all 60 fields, 36 and 70 sampling sites (one or two sampling sites within a field) in 2014 and 2015, respectively. The soil samples were transported to the laboratory on ice and processed immediately upon arrival. Soil samples were analyzed for 12 soil properties (Supplementary Table S1). Particle size analysis (sand, silt, clay) was conducted using the Hydrometer method (Tan 1996). $\mathrm{NO}_{3}{ }^{-} \mathrm{N}, \mathrm{PO}_{4}{ }^{{ }^{-}}, \mathrm{K}^{+}, \mathrm{pH}, \mathrm{EC}, \mathrm{Zn}^{2+}, \mathrm{Fe}^{2+}$, organic matter, and calcium carbonate equivalent (CCE) were analyzed by the Soil Testing Laboratory at North Dakota State University using standard methodology (Carson 1980; Combs and Nathan 1998; Corwin and Rhoades 1982; Lindsay and Norvell 1978; McLean 1982; Olsen et al. 1954; Williams 1949).

Disease evaluation

Disease incidence data were used to establish associations among soil-borne pathogen communities, soil properties and root rot incidence and develop prediction models. Plants were rated for disease using a modified disease rating scale where $0=$ no root discoloration; $1=$ slight discoloration of less than $15 \%$ of the root; $2=$ moderate discoloration that covers 16 to $30 \%$ of the root; $3=$ large discolored lesions that cover 31 to $75 \%$ of the root with some shriveling root hairs; $4=$ extensive root discoloration from 76 to $100 \%$ of the root but epicotyl is not shrunken; $5=100 \%$ discoloration of the root with lateral roots completely rotted and a shrunken epicotyl and/or roots are severed (Infantino et al. 2006; Ondrej et al. 2008). The ratings were transformed into binary data, where plants with a disease rating of 3 and above were considered diseased (1) and plants with a rating of 2 and below were considered healthy ( 0$)$. The frequency of diseased plants (disease incidence) was determined at each of the 106 sampling sites where both plants and soil were sampled. Rather stringent parameters were applied to the classification of sampling sites. Soil/plant sampling sites with two or more diseased plants among the five sampled was considered a diseased site (1). Soil/plant sampling sites with zero 
or one diseased plant were considered a diseasefree site $(0)$.

Isolation and identification of fungi and oomycetes

Fungi and oomycete organisms were recovered from root tissue and identified via morphology and sequencing. Five, 2-cm sections were arbitrarily excised from the taproot, primary and secondary roots of each plant and placed onto three types of solid growth media in $90 \mathrm{~mm}$ Petri plates using the under the block technique (Schmitthenner and Bhat 1994). In total, fifteen sections were excised from across the entire root system of each plant to maximize the isolation of all potential pathogens. Isolations were targeted at Fusarium spp., $R$. solani, A. euteiches and Pythium spp. as these have been identified as the most common pathogens associated with field pea in the northern great plains of the US and Canada (Chatterton et al. 2016; Chittem et al. 2015; Feng et al. 2010; Gossen et al. 2016; Mathew et al. 2008; Zitnick-Anderson et al. 2018). For potential isolation of Fusarium species and $R$. solani, $1 / 2$ strength potato dextrose agar ( $1 / 2$ PDA: $19.5 \mathrm{~g}$ of BD Difco ${ }^{\mathrm{TM}}$ potato dextrose agar, $7.5 \mathrm{~g}$ agar, $1 \mathrm{~L}$ of distilled $\mathrm{H}_{2} \mathrm{O}$ ) amended with streptomycin and neomycin both at a concentration of $50 \mathrm{mg} / \mathrm{L}(1 / 2$ PDA-S $+\mathrm{N})$ was utilized. Roots plated onto the $1 / 2 \mathrm{PDA}-\mathrm{S}+\mathrm{N}$ were incubated at $22 \pm 2{ }^{\circ} \mathrm{C}$ for three to five days under alternating $12 \mathrm{~h}$ light:dark. Growth on all plates was examined at $10 \times$ and $20 \times$ magnification using a BX43 clinical microscope (Olympus, Center Valley, PA) under phase-one lighting. Cultures were purified using hyphal-tip methods and placed onto non-amended $1 / 2$ PDA. After three to five days, single spores typical of Fusarium spp. were transferred to carnation leaf agar (CLA, BD Biosciences; Nelson et al. 1983). Isolates were incubated as previously described for cultures of Fusarium species on $1 / 2 \mathrm{PDA}-\mathrm{S}+\mathrm{N}$. Isolates were identified to Fusarium spp. using morphological features including macro- and microconidial shape and size, the presence of sporodochia and chlamydospores and culture pigmentation (Leslie and Summerell 2006). Hyphal apices characteristic of $R$. solani were transferred to $1 / 2$ PDA$\mathrm{S}+\mathrm{N}$ via micro-manipulation and incubated for four to five days at $22 \pm 2{ }^{\circ} \mathrm{C}$ (Sneh et al. 1991). R. solani was characterized based on the presence of septate hyline hyphae that developed hyphal branching at a $90^{\circ}$ angle and the characteristic brown radial colony growth (Sneh et al. 1991).
Isolation of Pythium spp. was conducted on media containing $1 \%$ agar (water agar; WA: $15 \mathrm{~g}$ of BD Bacto ${ }^{\mathrm{TM}}$ dehydrated agar, $1 \mathrm{~L}$ of distilled $\mathrm{H}_{2} \mathrm{O}$ ) amended with $5 \mathrm{mg}$ of primaricin, $250 \mathrm{mg}$ sodium ampillicin, $10 \mathrm{mg}$ rifampicin, $133.3 \mathrm{mg} 75 \%$ pentachloronitrobenzene (PCNB), and $10 \mathrm{mg}$ benomyl (WA- PARP+B; Oudemans 1999). A. euteiches isolation was conducted using cornmeal agar (CMA: 17 g BD BBL ${ }^{\mathrm{TM}}$ cornmeal agar / $1 \mathrm{~L}$ distilled $\mathrm{H}_{2} \mathrm{O}$ ) amended with $100 \mathrm{mg}$ metalaxyl, $10 \mathrm{mg}$ benomyl, $100 \mathrm{mg}$ vancomycin, $100 \mathrm{mg}$ rifampicin, and $.05 \mathrm{mg}$ amphotericin b (CMA-MBV; Pfender et al. 1984). Roots plated onto these oomycete-selective media were incubated for $48 \mathrm{~h}$ as described above for fungal isolation. Defining oomycete characteristics such as coenocytic hyphae with flowing protoplasm were used to select isolates for transfer. Hyphal apices characteristic of oomycetes were placed onto $1 / 2$ PDA-S $+\mathrm{N}$. Isolates of Pythium spp. and A. euteiches were identified to species via morphological features. The size and shape of asexual structures including sporangia, zoospores, and hyphal ornamentation and sexual structures including oospores, oogonium, and antheridia primarily were used for morphological identification (van der Plaats-Niterink 1981; Dick 1990; Scott 1961). Isolates of Pythium spp. that did not readily produce sexual structures on media were cultured in a grass leaf culture (Zitnick-Anderson and Nelson 2015). Asexual structure development and storage of $A$. euteiches isolates were performed previously described (Carlson 1965; Dick 1990; van der Plaats-Niterink 1981; Scott 1961).

All fungal and oomycete isolates collected in 2014, and approximately $50 \%$ of isolates collected in 2015 were sequenced to confirm morphological identities. Total genomic DNA was extracted from purified cultures for species identification via sequencing. After 5 and 7 days, fungal and oomycete tissue, respectively, was scraped from the agar surface for each purified fungal isolate and lyophilized using a Labconco Freezone 6 console freeze dry system (Labconco, Kansas City, MO) for $24 \mathrm{~h}$ at $-40{ }^{\circ} \mathrm{C}$ under $0.133 \mathrm{mBar}$ of vacuum pressure. Dried tissue was transferred to $2 \mathrm{~mL}$ round bottom screw cap cryovials (Cat. \# 10018-746, VWR, Radnor, PA) and total genomic DNA was extracted using a modified CTAB method (Doyle and Doyle 1987; Zitnick-Anderson et al. 2018). DNA quantity and quality were evaluated using Nanodrop and gel electrophoresis on a $1 \%$ agarose gel, respectively. The internal transcribed spacer (ITS) primers ITS1 and ITS4 were used to sequence all isolates (White et al. 1990). Further confirmation of the isolate identity as Fusarium 
spp., or an oomycete (Pythium spp. or A. euteiches) was performed in duplicate using the translation elongation factor alpha 1 (TEF- $1 \alpha)$ EF-1 and EF-2 primers and coxidase subunit I (COXI) mitochondrial DNA primers OomCOILevup and FM58mod, respectively, using previously described methods (Broders et al. 2009; Knutsen et al. 2004; Spies et al. 2011). Amplified PCR products were visualized via electrophoresis on a $1 \%$ agarose gel. The PCR products were treated with Exo-I (Affymetrix, $\mathrm{OH}$ ) and rAPid phosphatase (Roche, IN) following the manufacturer's protocol and sequenced bi-directionally (GenScript USA Inc., Piscataway, NJ). DNA sequence data were compared with known sequences available in the NCBI non-redundant database to confirm morphological identification. The FUSARIUM-ID v 1.0 database was used to evaluate sequences from those isolates morphologically identified as Fusarium spp. and sequenced using the TEF- $1 \alpha$ primers. BLAST parameters included sequence lengths ranging from 600 to $850 \mathrm{bp}$, e-values of 0.0 , maximum identity match of $98 \%$ or greater, and query coverage of $98 \%$ or greater (Supplementary Table S2).

Species diversity, evenness and Spearman's correlation

Species diversity and evenness were calculated using the number of isolates of each species at each soil sampling site within a field using the Shannon and evenness $\mathrm{E}_{5}$ indices (Grünwald et al. 2003; Krebs 1999). The Shannon index is described as $\mathrm{H}^{\prime}=\Sigma p_{i} \ln$ $p_{i}$, where $\mathrm{H}^{\prime}$ is species diversity score and $p i$ is the proportion of individuals in the $i$ th species (Krebs 1999). The $E_{5}$ equation is as described as $E_{5}=(((1 / \lambda)-$ $1) / \mathrm{e}^{\mathrm{H}^{\prime}}-1$ ), where $\lambda$ is Simpson's index (Grünwald et al. 2003). The Simpson's index is a measure of diversity that accounts for the number of species present and the abundance of each species (Grünwald et al. 2003; Krebs 1999). Relationships between species diversity and the 12 soil properties were evaluated using Spearman's correlation analysis (SAS version 9.1; SAS Institute, Cary, NC).

Development and characterization of soil-borne pathogen communities

Differences across soil environments, with communities as sample units, can be conceptualized using indicator species analysis (Dufrêne and Legendre 1997). For the purpose of this study, communities were defined by geographical distribution based on the occurrence of targeted soil-borne pathogens isolated from plants collected at each soil sampling site. To avoid generalizing soil information for an entire field, soil-borne pathogen abundance and frequency data used for the indicator species analysis was limited to plants sampled from the same site within a field where soil samples were extracted. Abundance was defined as total number of isolates of each species recovered from plants at a soil sampling site. The frequency of occurrence of each species was defined as the number of sites where a species was identified/ total number of soil sampling sites $(n=106) \times 100$.

A square root transformation was utilized to transform non-linear and non-normal frequency and abundance data for each organism. Hierarchical clustering, indicator species analysis, and multi-response permutation procedure (MRPP) were used to develop and characterize the community structure of the fungi and oomycetes in the soil-borne pathogen complex using the PC-ORD version 6 software (McCune and Mefford 2011). Indicator species analysis was validated using a previously developed 5-step process (Siddig et al. 2016). Communities within the pea root rot complex were described using the results of the hierarchical clustering of sampling sites and indicator species analysis.

Hierarchical cluster analysis was performed using the relative Euclidean distance measurement and Ward's minimum variance method to group sampling sites together based on combining relative abundance and frequency of each species. The dendrogram was used to define and determine the optimum number of communities by implementing the Dufr ne and Legendre (1997) method of pruning based on indicator species analysis (McCune and Mefford 2011).

Community membership was analyzed and indicator values were calculated for each species within a community at each cluster step. Within the indicator species analysis, the Monte Carlo test was performed to generate $p$ values for each species and the average $p$ value across all species (McCune and Mefford 2011). The cluster step with the smallest average $p$ value and the most significant indicators $(\alpha \leq 0.05)$ were used as criterion for determining communities within the data set. In addition, a MRPP was performed to determine if communities were statistically dissimilar (McCune and Mefford 2011; Mielke and Berry 2001). The test statistic $(T)$ was used to assess the separation between the field 
pea soil-borne pathogen communities. Additionally, the likelihood that observed differences among communities was due to chance value (p) and the chancecorrected within community agreement value $(A)$ were used to evaluate the validity of the communities (McCune and Mefford 2011; Mielke and Berry 2001).

Modeling and associations

Logistic regression analysis was performed using the presence/absence (occurrence) data for each soil-borne pathogen community, disease and the soil properties data. Logistic regression analysis was performed using stepwise selection to generate multiple models to determine associations among soil properties, disease incidence and occurrence data of each soil-borne pathogen community. After computing the $y$ values from the logistic models, probabilities of the presence of diseased plants and communities of soil-borne pathogen were calculated using the same formula $\left(P=\mathrm{e}^{\mathrm{y}} /\left(1+\mathrm{e}^{\mathrm{y}}\right)\right)$, where $P$ is probability and $\mathrm{e}^{\mathrm{y}}$ linearizes the logistic $y$ values. Logistic regression was performed using SAS (version 9.3). The Akaike Information Criterion (AIC), $c$-value (a variant of Somer's D), and Hosmer and Lemeshow test were used to evaluate the quality and the fitness, respectively, of each model for the data (Hosmer et al. 1988; Sakamoto et al. 1986; Somers 1962). The AIC value measured the amount of information loss for each model developed for each soil-borne pathogen community and disease incidence. The $c$-value is comparable to the R-square value of linear regression. The $c$-value was used to assess the accuracy of the models. The Hosmer and Lemeshow test was used to assess the accuracy of the model that best fits the data.

\section{Results}

Soil-borne pathogen isolation and identification

A total of 3376 isolates of Fusarium spp. R. solani, A. euteiches and Pythium spp. were recovered from 60 fields in 11 counties in northwestern North Dakota from field pea plants collected during the month of June in 2014 and 2015 (Table 1). Among these, 11 fungal and oomycete species were identified based on morphological and DNA sequence data (Tables 1 and 2). A. euteiches was recovered from plants sampled from nine of 11 North Dakota counties across 2 years
(Table 1). All Fusarium spp. were collected from either 10 or 11 counties. Pythium spp. and R. solani were recovered from 10 and five counties, respectively. Frequency of recovery of Fusarium spp. generally followed the same trends across both years the survey was conducted. In 2014, Fusarium avenaceum R.J. Cook, Fusarium acuminatum Wollenweber, and $F$. oxysporum were most frequently recovered from $69 \%, 67 \%$, and $45 \%$ of the 100 plant sampling sites, respectively (Table 2). A. euteiches, $R$. solani and Pythium spp. were recovered from $17 \%, 7 \%$ and $6 \%$ of the 100 plant sampling sites, respectively. In 2015, F. acuminatum (74\%), F. avenaceum (60\%), and Fusarium redolens (Wollenweber) W.L. Gordon (35\%) were most frequently recovered (Table 2). A. euteiches, and Pythium spp. were recovered more frequently in 2015, from $25 \%$ and $11 \%$ of the 200 plant sampling sites, respectively. $R$. solani was not recovered from any plants sampled in 2015. Detection frequency of all other Fusarium spp. across both years was between $9 \%$ and $28 \%$.

Species diversity, evenness, and Spearman's correlation

The Shannon diversity indices, ranged from 0.59 to 2.04 for fungal and oomycete species. The Simpson's indices measuring evenness were high, ranging from 0.69 to 0.97. Spearman correlation analyses between species diversity and the 12 soil properties revealed a significant $(p=0.02 ; \rho=-0.22)$ negative correlation between $\mathrm{K}^{+}$ and species diversity. No other correlations were significant between species diversity and the other 11 soil properties (data not shown).

Development and characterization of soil-borne pathogen communities

Five communities were defined using the cluster analysis, indicator species analysis, and MRPP (Table 3). Cluster step five had the greatest number of significant indicator species and the lowest average $p$ value across all species; therefore, this was the most informative and ecologically meaningful point to prune the dendrogram $(p=0.25)$. The three MRPP tests included to evaluate the validity of each community defined by the indicator species indicated that there were statistical differences among communities $(T=-41.33)$, the differences between communities was not due to chance $(p=0.004)$, and the communities were heterogeneous $(A=0.04)$. Based on the indicator species analysis, community 1 


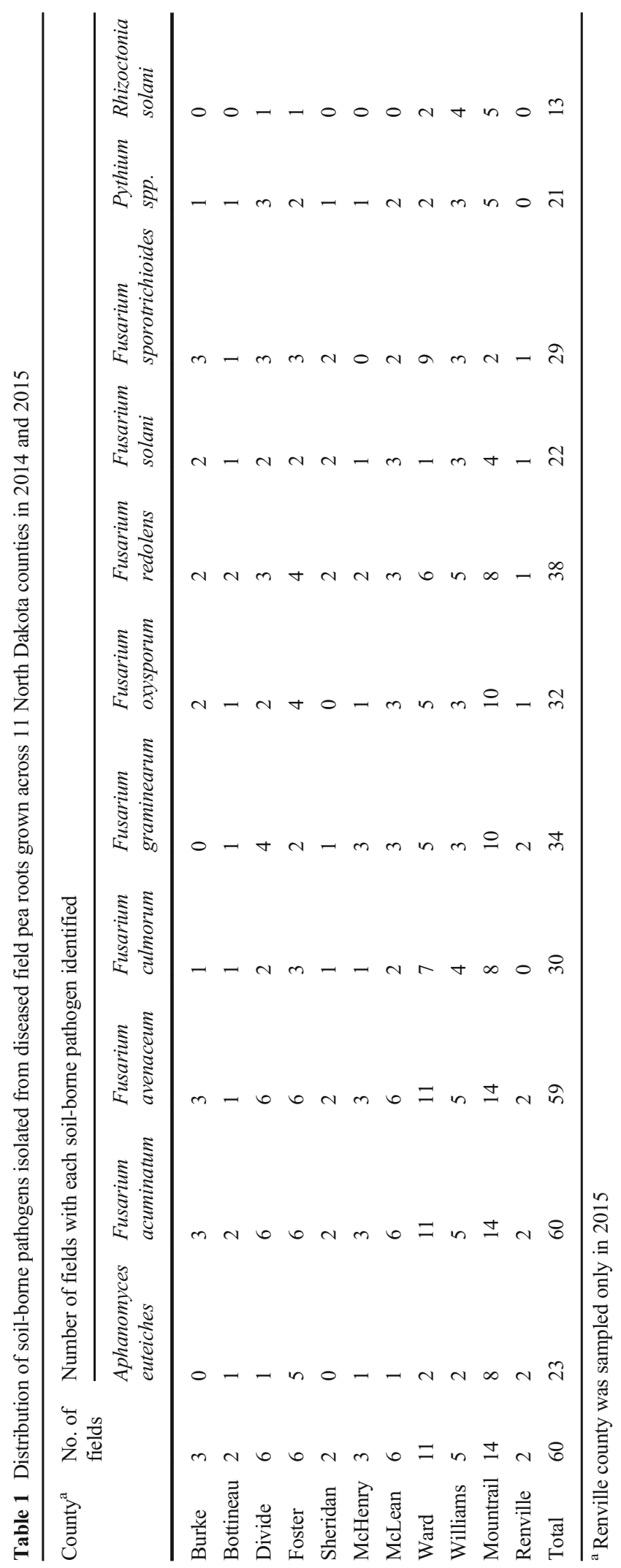


Table 2 Frequency of soil-borne pathogens recovered from North Dakota field peas surveyed in 2014 and 2015

\begin{tabular}{llll}
\hline Pathogens & 2014 & 2015 & Total $^{\text {Frequency }(\%)^{\mathrm{c}}}$ \\
\hline Aphanomyces euteiches & ${\text { Frequency }(\%)^{\mathrm{a}}}^{\mathrm{b}}$ & ${\text { Frequency }(\%)^{\mathrm{b}}}$ & 22 \\
Fusarium acuminatum & 17 & 25 & 71 \\
Fusarium avenaceum & 67 & 74 & 63 \\
Fusarium culmorum & 69 & 60 & 18 \\
Fusarium graminearum & 11 & 22 & 21 \\
Fusarium oxysporum & 25 & 20 & 34 \\
Fusarium redolens & 45 & 28 & 28 \\
Fusarium solani & 15 & 35 & 10 \\
Fusarium sporotrichioides & 11 & 9 & 18 \\
Pythium spp. & 12 & 22 & 9 \\
Rhizoctonia solani & 6 & 11 & 2 \\
\hline
\end{tabular}

${ }^{\mathrm{a}}$ Frequency based on the presence of each pathogen across 100 plant sampling sites during 2014

${ }^{\mathrm{b}}$ Frequency based on the presence of each pathogen across 200 plant sampling sites during 2015

${ }^{\mathrm{c}}$ Frequency based on the presence of each pathogen across the total 300 plant sampling sites for 2014 and 2015

was characterized by $F$. acuminatum, present at 33 sampling sites. Community 2 was characterized by F. solani, present at 8 sampling sites. Community 3 was characterized by $A$. euteiches, present at 24 sampling sites. Community 4 was characterized by Fusarium sporotrichioides Sherbakov, present at 31 sampling sites. Community 5 was characterized by $F$. redolens, present at 10 sampling sites.

Probability models and associations

Logistic regression analysis was performed to generate an accurate model to calculate the probability of the occurrence of each community based on the soil properties. Logistic regression models generated for community 2 (characterized by $F$. solani) and 5 (characterized by $F$. redolens) did not fit the data and were rejected based on the Hosmer and Lemeshow test values of 0.02 and $<0.01$, respectively. This is likely because there was insufficient data to make any significant or meaningful associations. Community 2 was only present at 8 sampling sites and community 5 was only present at 10 sampling sites. The communities were significant based on the indicator species analysis; however, extrapolating associations between the occurrence of each community and soil properties using logistic regression is not appropriate with so few points of observation.

Logistic regression models were chosen for each of the three communities with significant associations based on the lowest AIC values, the largest $c$-values and Hosmer and Lemeshow $p$-values. The rank correlation of ordinal variables ( $c$ value) and the accuracy of the model for fit to the data (Hosmer and Lemeshow test) for community 1 (characterized by $F$. acuminatum) were 0.70 and 0.86 , respectively. Both values indicate that the model extrapolated from logistic regression analysis was a good fit for the data. The logistic regression model for community 1 was $\operatorname{logit}(\mathrm{y})=2.24+$ -0.0968 (clay). The model for community 1 indicated that as clay content increased, the probability of the occurrence of community 1 within a soil decreased ( $p<0.01$; Fig. 1).

For community 3 (characterized by A. euteiches), the $c$ value was 0.74 and the Hosmer and Lemeshow test was 0.84 . The logistic regression model was logit $(\mathrm{y})=$ $-8.9913+-0.00524\left(\mathrm{~K}^{+}\right)+1.0294(\mathrm{pH})+0.0232\left(\mathrm{Fe}^{2+}\right)$. Logistic regression analysis indicated that community 3 was positively associated with, $\mathrm{pH}(p=0.01)$ and $\mathrm{Fe}^{2+}$ $(p<0.01)$ and negatively associated with $\mathrm{K}^{+}(p=0.01)$. However, when held at constant $\mathrm{pH}$ of 7 , as $\mathrm{K}^{+}$levels increased the overall probability of the occurrence of community 3 decreased across a range of $\mathrm{Fe}^{2+}$ concentrations (Fig. 2).

The $c$ value was 0.78 and the Hosmer and Lemeshow test was 0.62 for community 4 (characterized by $F$. sporotrichioides). The logistic regression model was logit $(\mathrm{y})=3.3683+$ $-1.1847(\mathrm{pH})+-0.019\left(\mathrm{Fe}^{2+}\right)+0.1727(\mathrm{clay})$. 
Table 3 Monte Carlo test and indicator species analysis showing the indicator values of each soil-borne pathogen for each group (cluster) recovered from field pea roots sampled in North Dakota in 2014 and 2015

\begin{tabular}{|c|c|c|c|c|c|c|c|c|c|c|c|}
\hline \multirow[b]{4}{*}{ Pathogen } & \multirow[b]{4}{*}{$\operatorname{Avg}^{b}$} & & & \multicolumn{5}{|c|}{ Community } & \multirow{2}{*}{\multicolumn{3}{|c|}{$\begin{array}{l}\text { Monte Carlo test of significance of } \\
\text { observed maximum indicator values } \\
\text { for indicator species }\end{array}$}} \\
\hline & & \multicolumn{2}{|c|}{ Identifier $^{\mathrm{a}}$ : } & \multirow{3}{*}{$\begin{array}{l}1 \\
33\end{array}$} & \multirow{2}{*}{$\begin{array}{l}2 \\
8\end{array}$} & \multirow{2}{*}{$\begin{array}{l}3 \\
24\end{array}$} & \multirow{2}{*}{$\begin{array}{l}4 \\
31\end{array}$} & \multirow{3}{*}{$\begin{array}{l}5 \\
10\end{array}$} & & & \\
\hline & & \multicolumn{2}{|c|}{ Number of sampling sites: } & & & & & & & & \\
\hline & & $\operatorname{Max}^{\mathrm{c}}$ & $\operatorname{MaxGrp}^{\mathrm{d}}$ & & ator & Value & $(\%)$ & & Mean & S. Dev & $p$ value \\
\hline Fusarium avenaceum & 10 & 21 & 3 & 8 & 5 & 21 & 9 & 7 & 17.1 & 4.0 & 0.13 \\
\hline Fusarium acuminatum & 10 & 27 & 1 & 27 & 16 & 5 & 1 & 0 & 14.0 & 4.4 & 0.02 \\
\hline Fusarium graminearum & 10 & 19 & 2 & 7 & 19 & 6 & 7 & 10 & 15.9 & 4.3 & 0.19 \\
\hline Fusarium oxysporum & 9 & 13 & 3 & 9 & 12 & 13 & 7 & 4 & 16.3 & 4.3 & 0.80 \\
\hline Fusarium culmorum & 10 & 15 & 4 & 3 & 5 & 13 & 15 & 13 & 16.3 & 4.2 & 0.56 \\
\hline Fusarium sporotrichioides & 11 & 31 & 4 & 5 & 6 & 3 & 31 & 11 & 16.9 & 4.2 & 0.01 \\
\hline Fusarium redolens & 10 & 24 & 5 & 5 & 3 & 10 & 9 & 24 & 15.7 & 4.2 & 0.02 \\
\hline Fusarium solani & 6 & 22 & 2 & 4 & 22 & 1 & 1 & 4 & 10.7 & 4.6 & 0.04 \\
\hline Aphanomyces euteiches & 11 & 41 & 3 & 10 & 0 & 41 & 1 & 2 & 14.6 & 4.6 & 0.00 \\
\hline Pythium spp. & 9 & 16 & 1 & 16 & 4 & 12 & 6 & 7 & 16.9 & 4.3 & 0.46 \\
\hline Rhizoctonia solani & 6 & 11 & 2 & 2 & 11 & 5 & 3 & 7 & 11.8 & 4.6 & 0.45 \\
\hline Average & 9 & 22 & & 9 & 9 & 12 & 8 & 8 & 15.1 & 4.3 & 0.25 \\
\hline
\end{tabular}

${ }^{\text {a }}$ A coding variable

${ }^{\mathrm{b}}$ Average of the combined abundance and frequency of each species divided by 5 , the total number of communities

${ }^{\mathrm{c}}$ Maximum indicator value of the species across the five communities, a high number identifies the indicator species

${ }^{\mathrm{d}}$ The identifier for the community with the largest indicator value

Community 4, was negatively associated with $\mathrm{pH}$ $(p=0.01), \mathrm{Fe}^{2+}(p=0.03)$, and positively associated with clay $(p<0.01)$. At $\mathrm{pH}=7$, the model for community 4 indicates that as $\mathrm{Fe}^{2+}$ increased, the probability of the occurrence of community 4 decreased over a range of percentage clay (Fig. 3).

The $c$ value was 0.84 and the Hosmer and Lemeshow test was 0.77 for disease incidence. The logistic regression model was $\operatorname{logit}(\mathrm{y})=-0.657+$ $-0.004\left(\mathrm{~K}^{+}\right)+1.5145( \pm$ community 1$)+2.556$ ( \pm community 3 ). The disease incidence was negatively associated with $\mathrm{K}^{+}$levels, and was positively associated with the presence of communities 1 (characterized by $F$. acuminatum) and 3 (characterized by A. euteiches; Fig. 4). As soil $\mathrm{K}^{+}$levels increased the probability of disease incidence generally declined. However, when both communities 1 and 3 were present, the probability of disease incidence remained high regardless of $\mathrm{K}^{+}$concentrations (Fig. 4). The probability of disease occurrence was greater when only community 3 was present when compared to when only community 1 was present.

\section{Discussion}

To our knowledge this is the first study where associations were made among characterized soil-borne pathogen communities, soil edaphic properties, and field pea root rot incidence. This is also the first instance where probability models were developed to predict the occurrence of the soil-borne pathogen communities and disease incidence on field pea. Associations between soil edaphic properties and fungal /oomycete communities have been well established over the past 60 years (Broders et al. 2009; Coleman et al. 2004; Rojas et al. 2016; Rousk et al. 2010; Zitnick-Anderson et al. 2017). Soil texture, $\mathrm{pH}, \mathrm{EC}$, macro- and micronutrients indirectly and directly affect diversity of fungal and oomycete organisms. In addition, tillage, use of cover crops, soil amendments, and weather conditions can influence the field pea soil-borne pathogen complex (Gossen et al. 2016) and interactions can lead to changes in community structures. Essentially, community composition changes based on both abiotic and biotic variables. While it is not feasible to include every soil 
Fig. 1 Probability (\%) of the presence of soil-borne pathogen community 1 (characterized by Fusarium acuminatum) on plant root tissue as a function of increases in clay content $(\%)$. Logistic regression model: $\mathrm{y}=$ $2.24+-0.0968$ (clay)

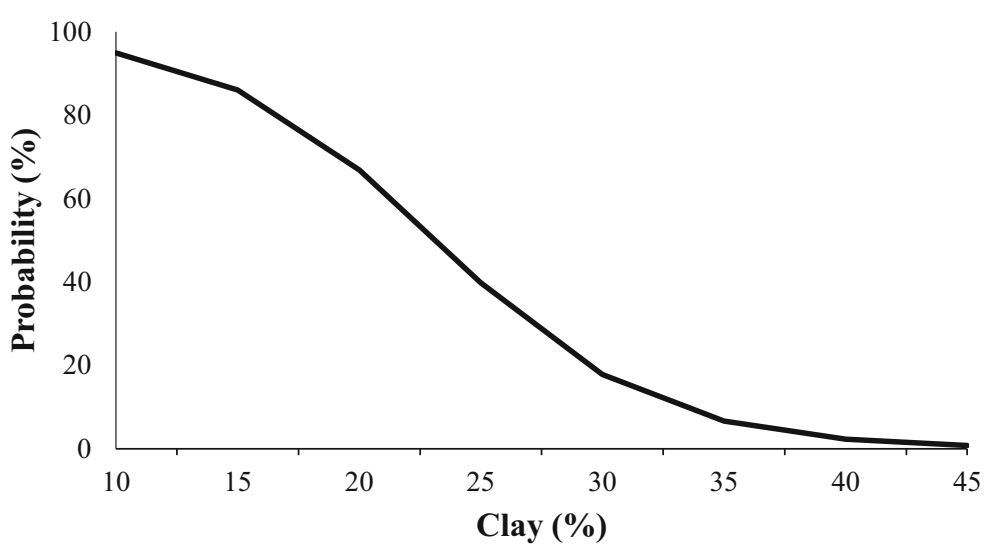

property that may influence community structure, analyzing 12 soil properties with the three soil-borne pathogen communities provided logistic models with statistical significance that explained the associations observed in this research. The information gained from the associations not only furthers our understanding of how some soil environmental parameters favor particular soil-borne pathogen communities, but also allows for the development of models to predict the likelihood of occurrence of a soil-borne pathogen community.

Soil-borne pathogens cause the most economically important diseases of field pea in the Northern Great Plains. Understanding the pathogens contributing to the disease complex is of utmost importance to management, in particular the development of cultivar resistance. Survey results from the current studies conducted in 2014 and 2015 confirm results from a previous North Dakota field pea surveys (Chittem et al. 2015; Mathew et al. 2008), further strengthening our understanding of the role Fusarium spp. and $R$. solani play in the soil-borne pathogen complex. Consistent with previous surveys in North Dakota and elsewhere, F. solani was found least frequently and $F$. acuminatum and $F$. avenaceum were found most frequently (Chatterton et al. 2016; Chittem et al. 2015; Feng et al. 2010; Mathew et al. 2008). Both $F$. solani and $F$. avenaceum are aggressive root rot pathogens on a wide host range and are globally distributed (Chatterton et al. 2016;

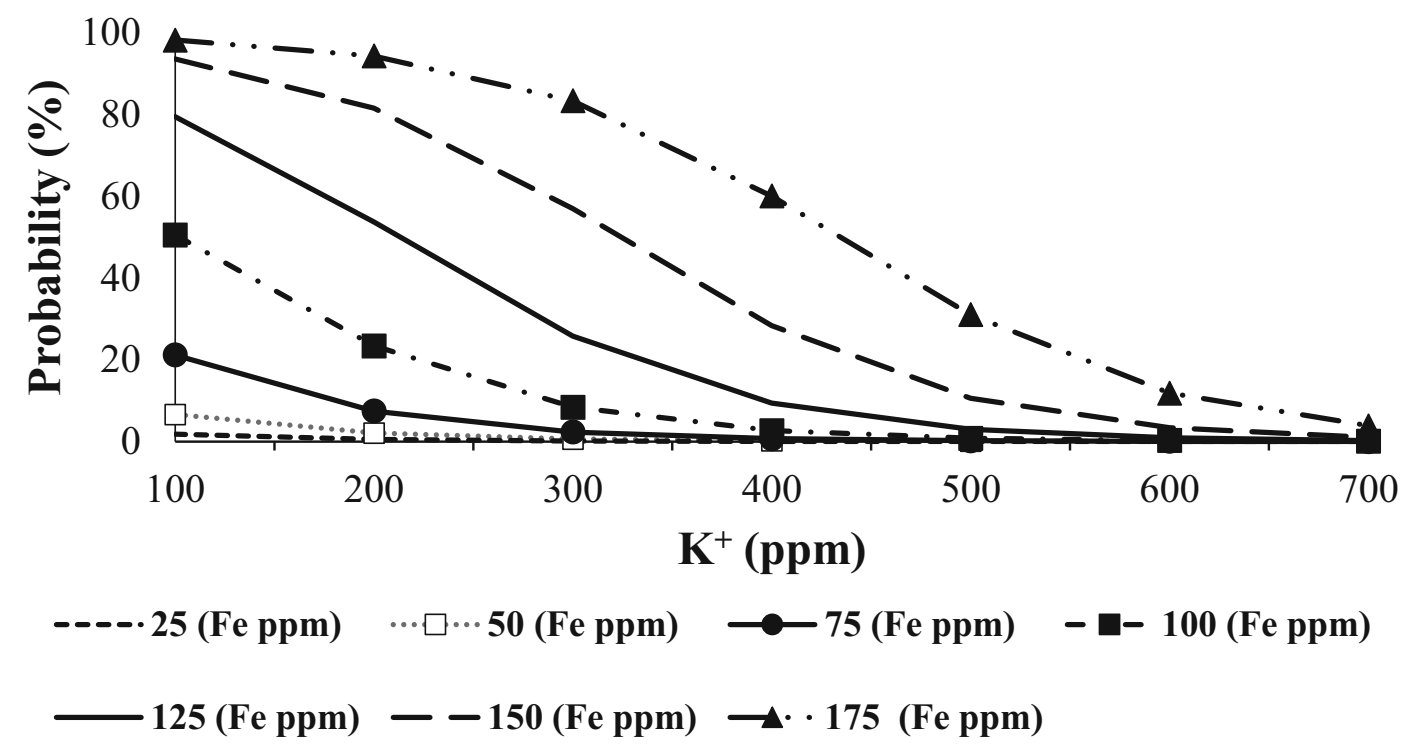

Fig. 2 Probability (\%) of the presence of soil-borne pathogen community 3 (characterized by Aphanomyces euteiches) on plant root tissue depending on $\mathrm{Fe}^{2+}, \mathrm{pH}$, and $\mathrm{K}^{+}$levels. Logistic

regression model: $\mathrm{y}=-8.9913+-0.00524\left(\mathrm{~K}^{+}\right)+1.0294(\mathrm{pH})$ $+0.0232\left(\mathrm{Fe}^{2+}\right)$. To simplify the representation of the model, $\mathrm{pH}$ was set at a constant of 7 

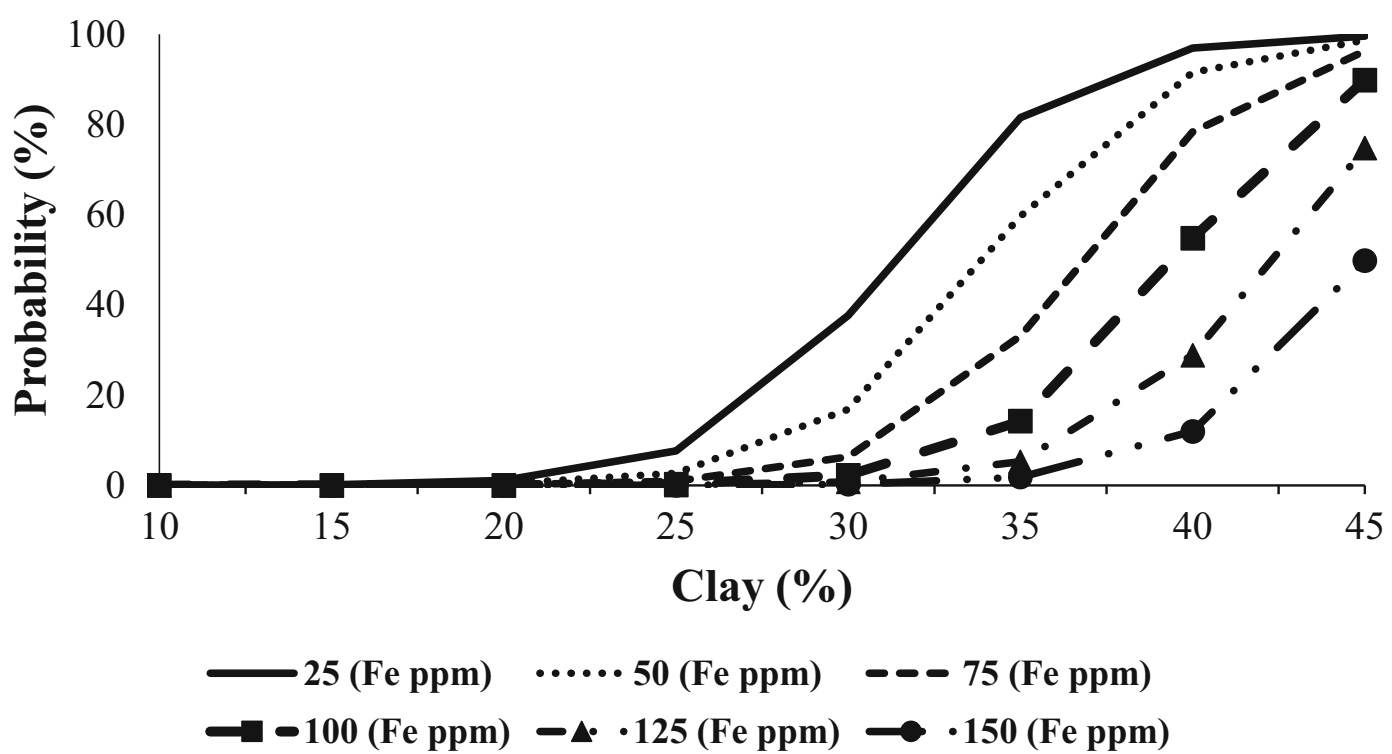

Fig. 3 Probability (\%) of the presence of soil-borne pathogen community 4 (characterized by Fusarium sporotrichioides) on plant root tissue depending on $\mathrm{Fe}^{2+}, \mathrm{pH}$, and clay percentage.

Chittem et al. 2015; Feng et al. 2010; Leslie and Summerell 2006; Mathew et al. 2008; ZitnickAnderson et al. 2018). The role other Fusarium spp. play in Fusarium root rot of field pea is largely unknown. Although some research has indicated that $F$. acuminatum, $F$. graminearum, $F$. redolens and $F$. sporotrichioides, cause negligible amounts of disease
The logistic regression model was $\mathrm{y}=3.3683+-1.1847(\mathrm{pH})+$ -0.019 (Fe) +0.1727 (clay). To simplify the representation of the model $\mathrm{pH}$ was set at a constant of 7

on the roots of field pea (Chittem et al. 2015; Días Arias et al. 2013; Rodrigues and Menezes 2005; ZitnickAnderson et al. 2018). R. solani appears to play a very minor role in root rot of field pea in North Dakota. This may be due in part to seed treatment fungicides managing this pathogen. In addition to characterizing the true fungi associated with field pea roots, the results of this

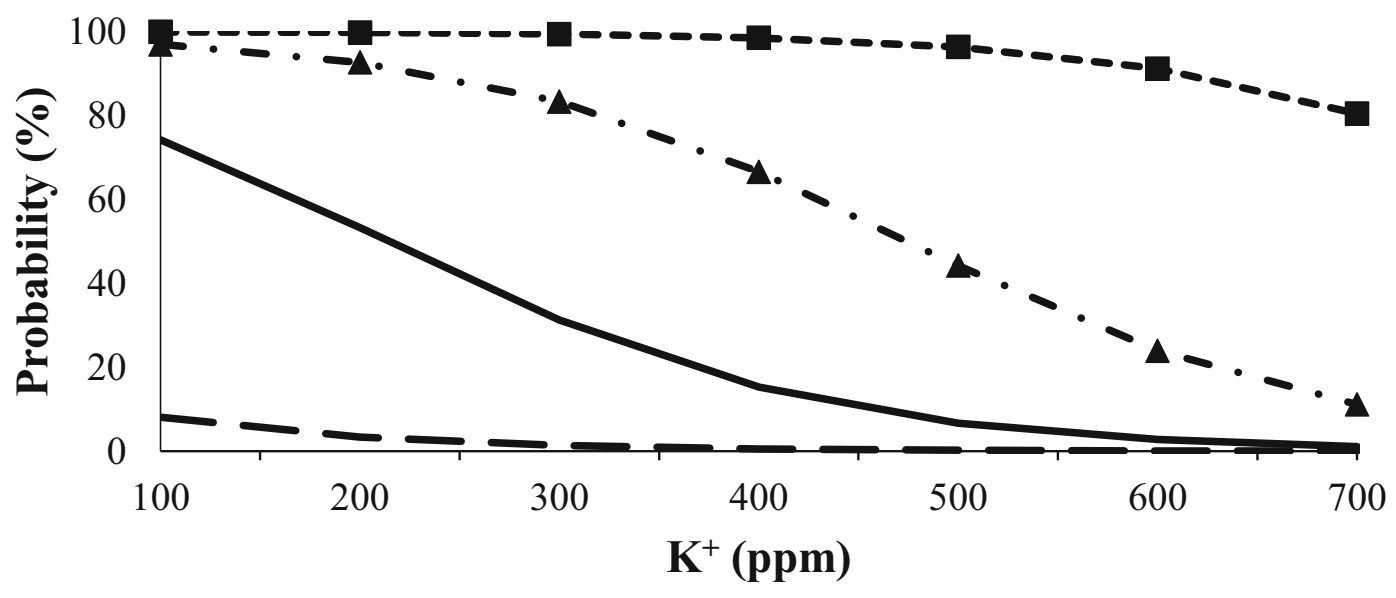

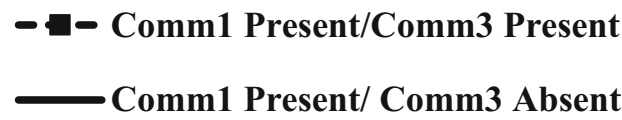

Fig. 4 Probability (\%) of disease incidence depending on the soil $\mathrm{K}^{+}$and the presence of communities 1 (characterized by Fusarium acuminatum) and 3 (characterized by Aphanomyces euteiches).

\section{- $\Delta \cdot \cdot$ Comm1 Absent/ Comm3 Present \\ - Comm1 Absent/Comm3 Absent}

The logistic regression model was $\mathrm{y}=-0.657+-0.004\left(\mathrm{~K}^{+}\right)+$ $1.5145( \pm$ group 1$)+2.556( \pm$ group 3$)$ 
research expound our understanding of the pea soilborne pathogen complex in North Dakota by including the important field pea pathogens, A. euteiches and Pythium spp. Similar to A. euteiches, and Fusarium spp., Pythium spp. have wide host ranges and are globally distributed. A. euteiches is a historically documented plant pathogen primarily found in field pea growing regions (CABI/EPPO 2016). While Pythium spp. were recovered from approximately $1 / 3$ of fields, the importance of these organisms in the complex needs further investigation. Defining the geographic distribution of A. euteiches across field pea growing regions of North Dakota is a paramount finding in the development of much needed management strategies for this devastating pea pathogen. Growers need to be vigilant in identifying fields infested with this pathogen, as the current best management practice is avoiding infested fields (Gossen et al. 2016). The variation in pathogens collected during this survey across fields and years may be attributed to differences in environmental parameters such as soil edaphic properties, among other things.

Soil ecologists have long studied the beneficial contributions of microbial communities, as opposed to individual species, within the soil substrate and the plant rhizosphere. When microbial diversity is high, the overall soil health is regarded as good (Hillel 2007). Approaching the soil-borne pathogen complex by redirecting the focus on communities rather than a single species has improved our understanding of associations between soil edaphic properties, the recovery of certain pathogenic microbial communities and disease incidence. Previous research has indicated that host resistance to a single pathogen identified in one site may not be effective across geography or environments (Abdullah et al. 2017; Hamon et al. 2011). In France, quantitative trait loci for resistance were determined to be effective, but when these resistant lines were planted in U.S. they were not resistant to the native A. euteiches population (Hamon et al. 2011). The authors concluded that the combination of a differing A. euteiches population and the presence of other soil microorganisms, mainly Fusarium spp., explained the site-specific resistance. To develop genetic resistance effective across environments, it is necessary to develop and optimize previously developed screening systems by incorporating interactions among multiple organisms within a community (Abdullah et al. 2017). While single organisms in screening methods produce valuable results, identifying the soil-borne pathogen communities associated with the field pea pathogen complex could improve the efficacy, repeatability and applicability of resistance screening methods performed in greenhouse and field environments.

Many plant diseases, particularly those caused by soil-borne pathogens, are caused by the interactions among a myriad of pathogens and should be considered in the context of complexes/communities rather than in isolation (Abdullah et al. 2017; Lamichhane and Venturi 2015). However, to date in field pea, researchers have not attempted to look at soil-borne pathogens as part of communities, nor have they studied the effects of the soil environment on the occurrence of these communities. The results presented here are the foundation for the development of new management strategies. The combination of community analysis and logistic modeling incorporate variables typically not accounted for in standard greenhouse or controlled field studies. This research is unique in that it observes soil-borne pathogen communities in the soil environment and identifies soil environmental parameters that dictate the occurrence of soil-borne pathogen communities.

The term indicator species has been used to describe communities in the past decade when monitoring environmental health and assessing early risk applications, such as models (Siddig et al. 2016). Indicator species are defined as an organism, either alone or in a group, whose occurrence or abundance reflects specific environmental conditions (McCune and Mefford 2011). In this study, we followed previous research using hierarchical clustering, indicator species and MRPP in determining communities of organisms within a data set (Broders et al. 2009, Dludlu et al. 2017, Siddig et al. 2016, Zitnick-Anderson et al. 2017). The Jaccard index is most commonly used for describing and defining communities from hierarchical clustering in phytopathological studies (Arnold and Lutzoni 2007; Broders et al. 2009), but this method only utilizes the richness of the species collected in a study and does not incorporate species abundance information (Magurran 2004). Indicator species analysis was chosen for this study because it combines both the data for species abundance and the exclusivity (frequency) of a species in a single community to generate numerical values that can be used to justify the community (Dufrêne and Legendre 1997).

Although $F$. acuminatum and $F$. sporotrichioides have been isolated from field pea roots, soybean roots and cowpea seeds; these organisms are either not pathogenic, or cause negligible amounts of disease (Chittem 
et al. 2015; Días Arias et al. 2013; Rodrigues and Menezes 2005; Zitnick-Anderson et al. 2018). While the associations and the subsequent probability models for the communities characterized by $F$. acuminatum and $F$. sporotrichioides with soil properties clay, $\mathrm{pH}$ and $\mathrm{Fe}^{2+}$ are informative, the role of each indicator species within the field pea soil-borne pathogen complex requires further investigation. The logistic regression model for community 3 (characterized by A. euteiches), indicated that in general, as $\mathrm{Fe}^{2+}$ and $\mathrm{pH}$ increased the probability of identifying community 3 increased. Numerous studies have examined the effects of soil $\mathrm{pH}$ and $\mathrm{Fe}^{2+}$ on disease caused by soil-borne pathogens with conflicting results, but the current study is among few that address the effects of $\mathrm{pH}$ and $\mathrm{Fe}^{2+}$ on A. euteiches. Previous in vitro and in vivo studies indicate that the incidence of Aphanomyces root rot on sugar beet caused by Aphanomyces cochlioides Drechsler was suppressed as $\mathrm{pH}$ increased (Olsson et al. 2019, 2011). Differences between the results could be due to differences in geographic locations and subsequent soils. In addition, lab studies occasionally yield results that do not translate to field conditions (Papavizas and Davey 1962; Persson and Olsson 2000). The difference in these results with those observed during this research may be explained by the effect of $\mathrm{Fe}^{2+}$. Mycelial growth of A. euteiches and A. cochlioides increases on synthetic media amended with $\mathrm{Fe}^{2+}$ (Herr 1973; Papavizas and Davey 1960).

Substantial research studying the effects of $\mathrm{K}^{+}$based soil amendments on disease suppression has been performed; however, little information has been provided that relates soil $\mathrm{K}^{+}$levels to disease incidence and soilborne plant pathogens (Datnoff et al. 2007; Janvier et al. 2007). The results of the current research indicated significant negative associations based on logistic regression associations between soil $\mathrm{K}^{+}$and the occurrence of community 3 (characterized by A. euteiches), and disease incidence. These results are supported by numerous previous studies that have shown the suppressive qualities of increased $\mathrm{K}^{+}$-based soil amendments to root rot severity (Datnoff et al. 2007; Eyre 2016; Luedders et al. 1979; Kandji et al. 2001).

The effect of $\mathrm{K}^{+}$on the growth and zoospore viability has been studied in several oomycete organisms. In vitro $\mathrm{K}^{+}$concentrations greater than $2.47 \mathrm{mM}$ reduced Phytophthora sojae (Kaufmann and Gerdemann 1958) zoospore release and resulted in a reduction of disease severity under field conditions (Sugimoto et al. 2007).
In vitro zoospore motility of Phytophthora, Pythium, and Achlya spp. decreased as the concentration of various forms of $\mathrm{K}^{+}$increased (Appiah et al. 2005; Thomas and Butler 1989). In aquaculture, $\mathrm{K}^{+}$-based pesticides are commonly utilized to suppress disease caused by aquatic Aphanomyces spp. (Campbell et al. 2001; Hanjavanit et al. 2013; Klingker and Francis-Floyd 2002; Marecaux et al. 2006). Increasing concentrations of $\mathrm{K}^{+}$reduced hyphal growth, and zoospore germination and viability of Aphanomyces invadans Willoughby, Roberts \& Chinabut 1995, Aphanomyces astaci Schikora, and an unknown Aphanomyces spp. (Campbell et al. 2001; Hanjavanit et al. 2013; Sensson and Unestam 1975). The results from these previous studies demonstrate the deleterious effects of $\mathrm{K}^{+}$-based aquatic pesticides on Aphanomyces hyphal growth and zoospore germination, supporting associations made in this study that the probability of community 3 (characterized by $A$. euteiches) occurring within a field decreases as soil $\mathrm{K}^{+}$increases. The results from this study further suggest that community 3 (characterized by A. euteiches) is significantly associated with the probability of disease incidence. The model for disease incidence shows that when community 3 (characterized by A. euteiches) is present the probability of disease incidence increases. Therefore, if soil $\mathrm{K}^{+}$dictates the probability of community 3 (characterized by A. euteiches) occurring, then indirectly, the probability of disease incidence also can be predicted.

Although the models and associations may suggest the beneficial effects of soil $\mathrm{K}^{+}$for root rot disease suppression, management strategies may not be as easy as applying soil amendments with $\mathrm{K}^{+}$. The form of $\mathrm{K}^{+}$in fertilizers and amendments differentially affects disease caused by root rot pathogens and the dynamics between soil-borne pathogens, and the interactions between available $\mathrm{K}^{+}$and clay type may also affect disease (Datnoff et al. 2007; Franzen 2017; Persson and Olsson 2000). Further investigations evaluating the interactions between the naturally occurring $\mathrm{K}^{+}$ availability, clay type, and the occurrence of soilborne pathogens are needed before implementing a proposed management strategy. While many of the associations made between soil edaphic properties $\mathrm{K}^{+}, \mathrm{pH}, \mathrm{Fe}^{2+}$ and the occurrence of the soil-borne pathogen community 3 (characterized by A. euteiches) and disease incidence have been useful in developing probability models, empirical validation of these models is needed. 


\section{Conclusions}

Results from the current study provide a comprehensive examination into the field pea soil-borne pathogen complex in North Dakota. The incorporation of associations among multiple organisms from different genera and soil edaphic properties is unique and improves our understanding of the soil-borne pathogen complex associated with field pea. The results from the isolations of field pea roots indicated the presence of multiple pathogens; emphasizing the importance of shifting research foci from individual organisms to soil-borne pathogen communities associated with root disease of field pea. Ecological community statistics such as indicator species analysis are robust methods for characterizing soil-borne pathogen communities. Associations were established among the occurrence of these communities, soil edaphic properties, and disease incidence. Probability models generated from these associations emphasize the importance of investigating soil properties and how they affect the occurrence of communities of soil-borne pathogens. The development of probability models that predict the occurrence of the soil-borne pathogen communities is an important step in the development of more effective disease management practices. While the information generated in this study may be informative and applicable to the North Dakota field pea production regions, care must be taken when attempting to translate these results to other field pea production regions. This is the first example of using models to calculate the probability of finding soil-borne pathogens associated with field pea; however, further research is needed to validate the usefulness of these models across pea production regions.

Acknowledgements This study was supported by the Northern Pulse Growers Association and USDA- National Institute of Food and Agriculture (NIFA - Hatch project ND02229).

Open Access This article is licensed under a Creative Commons Attribution 4.0 International License, which permits use, sharing, adaptation, distribution and reproduction in any medium or format, as long as you give appropriate credit to the original author(s) and the source, provide a link to the Creative Commons licence, and indicate if changes were made. The images or other third party material in this article are included in the article's Creative Commons licence, unless indicated otherwise in a credit line to the material. If material is not included in the article's Creative Commons licence and your intended use is not permitted by statutory regulation or exceeds the permitted use, you will need to obtain permission directly from the copyright holder. To view a copy of this licence, visit http://creativecommons.org/licenses/by/4.0/.

\section{References}

Abdullah AS, Moffat CS, Lopez-Ruiz FJ, Gibberd MR, Hamblin J, Zerihun A (2017) Host-multi-pathogen warfare: pathogen interactions in co-infected plants. Front Plant Sci 8:1806

Agrios GN (1997) Plant pathology $4^{\text {th }}$ (ed). Academic press, New York, NY

Appiah AA, van West P, Osborne MC, Gow NAR (2005) Potassium homeostasis influences the locomotion and encystment of zoospores of plant pathogenic oomycetes. Fungal Genet Biol 42:213-223

Arnold AE, Lutzoni F (2007) Diversity and hot range of foliar fungal endophytes: are tropical leaves biodiversity hotspots? Ecology 88:541-549

Bailey KL, Lazarovits G (2003) Suppressing soil-borne diseases with residue management and organic amendments. Soil Till Res 72:169-180

Broders KD, Lipps PE, Paul PA, Dorrance AE (2009) Characterization of Pythium spp. associated with corn and soybean seed and seedling disease in Ohio. Plant Dis 91:727-735

CABI/EPPO (2016) Aphanomyces euteiches. [Distribution map]. Distribution Maps of Plant Diseases. Wallingford, UK: CABI, Map 78 (Edition 5)

Campbell RE, Lilley JH, Panyawachira V, Kanchanakhan S (2001) In vitro screening of novel treatments for Aphanomyces invadans. Aquac Res 32:223-233

Carlson LE (1965) Studies on the root rot of peas caused by Aphanomyces euteiches Drechs. University of Minnesota

Carson PL (1980) Recommended potassium test. In: Dahnke WC (ed) recommended chemical soil test procedures for the north central region. North central region publication 221. ND Agric Exp Stn, Fargo, pp 12-13

Chatterton S, Harding MW, Bowness R, Vucurevich C, Storozynsky Q, Dubitz T, Nielsen J, Olson M (2016) Survey of root rot in Alberta field pea in 2015. Can Plant Dis Surv 96:188-190

Chittem K, Mathew FM, Gregoire M, Lamppa RS, Chang YW, Markell SG, Bradley CA, Barasubiye T, Goswami RS (2015) Identification and characterization of Fusarium spp. associated with root rots of field pea in North Dakota. Eur J Plant Pathol 143:641-649

Coleman DC, Crossley DA Jr, Hendrix PF (2004) Fundamentals of soil ecology. Elsevier Inc, New York, NY

Combs SM, Nathan MV (1998) Soil organic matter. In: Brown JR (ed) Recommended chemical soil test procedures for the north central region (revised 1998). MI Agric Expt Sta NCR, MI, pp 53-58

Corwin DL, Rhoades JD (1982) An improved technique for determining soil electrical conductivity-depth relations from above-ground electromagnetic measurements. Soil Sci Soc Amer J 46:517-520

Coyne M (1999) Soil microbiology: an explanatory approach. Delmar Publishers, Albany, NY

Datnoff LE, Elmer WH, Huber DM (2007) Mineral nutrition and plant disease. American Phytopathological Society, St. Paul, MN

Días Arias MM, Munkvold GP, Ellis ML, Leandro LFS (2013) Distribution and frequency of Fusarium species associated with soybean roots in Iowa. Plant Dis 97:1557-1562

Dick MW (1990) Key to Pythium. UK, Reading

Dludlu MN, Chimphango SBM, Stirton CH, Muasya AM (2017) Distinct edaphic habitats are occupied by discrete legume 
assemblages with unique indicator species in the cape peninsula of South Africa. J Plant Ecol 11:632-644. https://doi. org/10.1093/jpe/rtx027

Doyle J, Doyle JL (1987) Genomic plant DNA preparation from fresh tissue-CTAB method. Phytochem Bull 19(11):11-15

Dufrêne M, Legendre P (1997) Species assemblages and indicator species: the need for a flexible asymmetrical approach. Ecol Monogr 61:53-73

Eyre M (2016) Characterizing the effect of increased phosphorus and potassium on seedling diseases and sudden death syndrome of soybean in Ohio: MS thesis. Ohio State University, Columbus, $\mathrm{OH}$

Feng J, Hwang R, Chang KF, Hwang SF, Strelkov SE, Gossen BD, Conner RL, Turnbull GD (2010) Genetic variation in Fusarium avenaceum causing root rot on field pea. Plant Pathol 59:845-852

Franzen D (2017) New potassium recommendations for North Dakota crops. North Dakota Cooperative Extension Service - Crop and Pest Report 16:13-14

Franzluebbers AJ, Haney RL, Hons FM, Zuberer DA (1996) Active fractions of organic matter in soils with different texture. Soil Biol Biochem 28:1367-1372

Geense P, Pattison AB, Kukulies TL, Scholberg JMS, Molina AB (2015) Can changes in soil properties in organic banana production suppress Fusarium wilt? Nat Resour J 6:181-195

Gossen B, Conner R, Chang K, Pasche J, McLaren D, Henriquez M, Chatterton S, Hwang S (2016) Identifying and managing root rot of pulses on the northern Great Plains. Plant Dis 100:1965-1978

Gregorich EG, Beare MH, McKim UF, Skjemstad JD (2006) Chemical and biological characteristics of physically uncomplexed organic matter. Soil Sci Soc Am J 70:975-985

Grünwald NJ, Goodwin SB, Milgroom MG, Fry WE (2003) Analysis of genotypic diversity data for populations of microorganisms. Phytopathol 93:738-746

Gu Z, Wang M, Wang Y, Zhu L, Mur LAJ, Hu J, Guo S (2020) Nitrate stabilizes the rhizospheric fungal community to suppress fusarium wilt disease in cucumber. Mol Plant Microbe In 33:590-599

Hamon C, Baranger A, Coyne CJ, McGee RJ, Le Goff I, L'Anthoëne V, Esnault R, Riviere JP, Klein A, Mangin P, McPhee KE (2011) New consistent QTL in pea associated with partial resistance to Aphanomyces euteiches in multiple French and American environments. Theor Appl Genet 123:261-281

Hanjavanit C, Panchai K, Kitancharoen N, Hatai K (2013) The antioomycetic effects of sodium chloride and potassium permanganate and the toxicity of these compounds to tilapia (Oreochromis niloticus) eggs. Afr J Microbiol Res 7:1852-1857

Herr LJ (1973) Growth of Aphanomyces cochlioides in synthetic media as affected by carbon nitrogen, methionine and trace elements. Can J Bot 51:2495-2503

Hillel D (1998) Environmental soil physics. Academic Press, San Diego, CA

Hillel D (2007) Soil in the environment: crucible of terrestrial life. Academic Press, San Diego, CA

Hosmer DW, Lemeshow S, Klar J (1988) Goodness-of-fit testing for the logistic regression model when the estimated probabilities are small. Biom J 30:911-924

Huber DM, Watson RD (1974) Nitrogen form and plant disease. Annu Rev Phytopathol 12:139-165

Infantino A, Kharrat M, Riccioni L, Coyne CJ, McPhee KE, Grünwald NJ (2006) Screening techniques and sources of resistance to root diseases in cool season legumes. Euphytica 147:201-221

Janvier C, Villeneuve F, Alabouvette C, Edel-Hermann V, Mateille T, Steinberg C (2007) Soil health through soil disease suppression: which strategy from descriptors to indicators? Soil Biol Biochem 39:1-23

Kandji ST, Ogol CKPO, Albrecht A (2001) Diversity of plantparasitic nematodes and their relationships with some soil physio-chemical characteristics in improved fallows in western Kenya. Appl Soil Ecol 18:143-157

Kaufmann MJ, Gerdemann JW (1958) Root and stem rot of soybean caused by Phytophthora sojae n sp Phytopathol 48

Klingker RE, Francis-Floyd R (2002) Introduction to freshwater fish parasites. Institute of Food and Agricultural Sciences, University of Florida no. CIR716, Florida Pp. 1-13

Knutsen AK, Torp M, Holst-Jensen A (2004) Phylogenetic analyses of the Fusarium poae, Fusarium sporotrichioides and Fusarium langsethiae species complex based on partial sequences of the translation elongation factor-1 alpha gene. Int J Food Microbiol 95:287-295

Krebs CJ (1999) Ecological methodology. Harper Collins Publishers, New York, NY

Lamichhane JR, Venturi V (2015) Synergisms between microbial pathogens in plant disease complexes: a growing trend. Front Plant Sci 6:385

Lehmann J, Rillig MC, Thies J, Masiello CA, Hockaday WC, Crowley D (2011) Biochar effects on soil biota -a review. Soil Biol Biochem 43:1812-1836

Leslie JF, Summerell BA (2006) The Fusarium laboratory manual. Vol 2 No 10. Blackwell. Ames, IA

Lindsay WL, Norvell WA (1978) Development of a DPTA soil test for zinc, iron, manganese, and copper. Soil Sci Soc Amer J 42:421-428

Luedders VD, Shannon JG, Baldwin CH (1979) Influence of rate and source of potassium on soybean cyst nematode reproduction on soybean seedlings. Plant Dis 63:558-560

Magurran AE (2004) Measuring biological diversity. Blackwell, Malden, MA

Marecaux EN (2006) Effect of potassium permanganate on the sailfin molly, Poecilia latippinna, at varying salinity levels. MSc Thesis, University of Florida, FL

Mathew FM, Barasubiye T, Markell SG, Goswami RS (2008) Detection and identification of Fusarium species in field pea roots. Phytopathol 98:6

Mazzola M, Hewavitharana SS, Strauss SL (2015) Brassica seed meal soil amendments transform the rhizosphere microbiome and improve apple production through resistance to pathogen reinfestation. Ecol Epidem 105:460-469

McCune B, Mefford MJ (2011) PC-ORD. Multivariate analysis of ecological data. Version 6. MjM software, Gleneden Beach, OR

McLean EO (1982) Soil pH and lime requirements. Pp 199-224 in page miller AL and Keeney DR (eds) methods of soil analysis. Part 2 chemical and microbiological properties $\left(2^{\text {nd }}\right.$ ed $)$ Agron 9: 199-223

Mielke PW, Berry KJ (2001) Permutation methods: a distance function approach. Springer-Verlag, Ann Arbor, MI

Nelson PE, Toussoun TA, Marasas WFO (1983) Fusarium species-an illustrated manual for identification. Pennsylvania State University Press, University Park, PA

Olsen SR, Cole CV, Watanabe FS, Dean LA (1954) Estimation of available phosphorus in soils by extraction with sodium 
bicarbonate. USDA circular 939, US government printing office Washington DC

Olsson Å, Persson L, Olsson S (2019) Influence of soil characteristics on yield response to lime in sugar beet. Geoderma 337: 1208-1217

Olsson Å, Persson L, Olsson S (2011) Variations in soil characteristics affecting the occurrence of Aphanomyces root rot of sugar beet-risk evaluation and disease control. Soil Bio Biochem 43:316-323

Ondrej M, Dostalova R, Trojan R (2008) Evaluation of virulence of Fusarium solani isolates on pea. Plant Protect Sci 44:9-18

Oudemans PV (1999) Phytophthora species associated with cranberry root rot and surface irrigation water in New Jersey. Plant Dis 83:251-258

Papavizas GC, Ayers WA (1974) Aphanomyces species and their root diseases in pea and sugarbeet: a review. United States department of agriculture. Washington, DC

Papavizas GC, Davey CB (1960) Some factors affecting growth of Aphanomyces euteiches in synthetic media. J Bot 47:758-765

Papavizas GC, Davey CB (1962) Control of Aphanomyces root rot of peas in the greenhouse with methionine and norleucine. Plant Dis Rep 46:646-650

Peng HX, Sivasithamparam K, Turner DW (1999) Chlamydospore germination and Fusarium wilt of banana plantlets in suppressive and conducive soils are affected by physical and chemical factors. Soil Biol Biochem 31:1363-1374

Persson L, Olsson S (2000) Abiotic characteristics of soils suppressive to Aphanomyces root rot. Soil Biol Biochem 32: $1141-1150$

Pfender WF, Delwiche PA, Grau CR, Hagedorn DJ (1984) A medium to enhance recovery of Aphanomyces from infected plant tissue. Plant Dis 68:845-847

Raaijmakers JM, Mazzola M (2016) Soil immune responses. Science 352:1392-1393

Rodrigues AAC, Menezes M (2005) Identification and pathogenic characterization of endophytic Fusarium species from cowpea seeds. Mycopathol 159:79-85

Rogovska N, Laird D, Leandro L, Aller D (2017) Biochar effect on severity of soybean root disease caused by Fusarium virguliforme. Plant Soil 413:111-126

Rojas A, Jacobs JL, Napieralski S, Karaj B, Bradley CA, Chase T, Esker P, Giesler L, Jardine D, Malvick D, Markell S, Nelson BD, Robertson A, Rupe JC, Smith D, Sweets L, Tenuta A, Wise K, Chilvers MI (2016) Oomycete species associated with soybean seedlings in North America - part II: diversity and ecology in relation to environmental and edaphic factors. Phytopathol 107:293-304

Rousk J, Bååth E, Brookes PC, Lauber CL, Lozupone C, Caporaso JG, Knight R, Fierer N (2010) Soil bacterial and fungal communities across a $\mathrm{pH}$ gradient in an arable soil. ISME J 4:1340-1351

Sakamoto Y, Ishiguro M, Kitagawa G (1986) Akaike information criterion statistics. Dordrecht, the Netherlands: D. Reidel 81

Schmitthenner AF, Bhat RG (1994) Useful methods for studying Phytophthora in the laboratory. Ohio Agricultural Research and Development Center, Special Circular 143

Scott WW (1961) A monograph of the genus Aphanomyces. Virginia agriculture Experiment Station. Blackburg, VA. Tech bull 151

Sensson E, Unestam T (1975) Differectial induction of zoospore encystment and germination in Aphanomyces astaci oomycetes. Physiol Plantarum 35:210-216
Siddig AAH, Ellison AM, Ochs A, Villar-Leeman C, Lau MK (2016) How do ecologists select and use indicator species to monitor ecological change? Insights from 14 years of publication in ecological indicators. Ecol Indic 60:223-230

Sneh B, Burpee L, Ogoshi A (1991) Identification of Rhizoctonia species. APS press

Spies CFJ, Mazzola M, Botha WJ, Van Der Rijst M, Mostert L, McLeod A (2011) Oogonial biometry and phylogenetic analyses of the Pythium vexans species group from woody agricultural hosts in South Africa reveal distinct groups within this taxon. Fungal Bio 115:157-168

Somers RH (1962) A new asymmetric measure of association for ordinal variables. Am Sociol Rev 1:799-811

Stone AG, Raina SJ, Hoitink HAJ (2001) Particulate organic matter composition and Pythium damping-off of cucumber. Soil Sci Soc Am J 65:761-770

Sugimoto T, Watanabe K, Yoshida S, Aino M, Matsuyama M, Maekawa K, Irie K (2007) The effects of inorganic elements on the reduction of Phytophthora stem rot disease of soybean, the growth rate and zoospore release of Phytophthora sojae. $\mathrm{J}$ Phytopathol 155:97-107

Tan KH (1996) Soil sampling, preparation, and analysis. Marcel Dekker, Inc, New York, NY

Thomas SS, Butler DL (1989) Cationic interactions regulate the initiation and termination of zoospore activity in the water mould Achlya heterosexualis. J Gen Microbiol 135:1917-1922

Trivedi P, Rochester IJ, Trivedi C, Van Nostrand JD, Zhou J, Karunaratne S, Anderson IC, Singh BK (2015) Soil aggregate size mediates the impacts of cropping regimes on soil carbon and microbial communities. Soil Biol Biochem 91:169-181

Tu JC (1986) Incidence and etiology of pea rots in southwestern Ontario. Can Plant Dis Surv 66:35-38

Tu JC (1991) Etiology, biology and control of a soilborne root rot complex of green peas. Plant Prot Bull 33:15-35

van der Plaats-Niterink AJ (1981) Monograph of the genus Pythium. Stud Mycol 21:1-242

Weller DM, Raaijmakers JM, Gardener BBM, Thomashow LS (2002) Microbial populations responsible for specific soil suppressiveness to plant pathogens. Annu Rev Phytophatol 40:309-348

White TJ, Bruns T, Lee SJWT, Taylor JL (1990) Amplification and direct sequencing of fungal ribosomal RNA genes for phylogenetics. PCR Meth Appl 18:315-322

Williams DE (1949) A rapid manometric method for the determination of carbonate in soils. Soil Sci Soc Am Proc 13:127-129

Zitnick-Anderson KK, Nelson BD Jr (2015) Identification and pathogenicity of Pythium on soybean in North Dakota. Plant Dis 99:31-38

Zitnick-Anderson KK, Norland JE, del Río Mendoza LE, Fortuna AM, Nelson BD (2017) Probability models based on soil properties for predicting presence-absence of Pythium in soybean roots. Microb Ecol 74:550-560

Zitnick-Anderson K, Simons K, Pasche JS (2018) Detection and qPCR quantification of seven Fusarium species associated with the root rot complex in field pea. Can J Plant Pathol 40:261-271

Publisher's note Springer Nature remains neutral with regard to jurisdictional claims in published maps and institutional affiliations. 